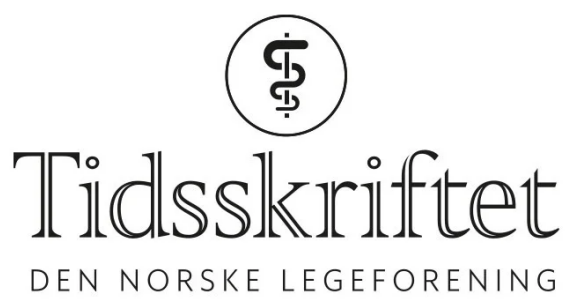

\title{
Hjelper motstandsventil på bagen ved gjenoppliving av nyfødte?
}

FRA ANDRE TIDSSKRIFTER

\section{KRISTOFFER BRODWALL}

kristoffer.brodwall@gmail.com

Barne- og ungdomsklinikken

Haukeland universitetssykehus

Tiltak for økt endeekspiratorisk trykk ga ingen effekt ved gjenoppliving av nyfødte i Tanzania. 


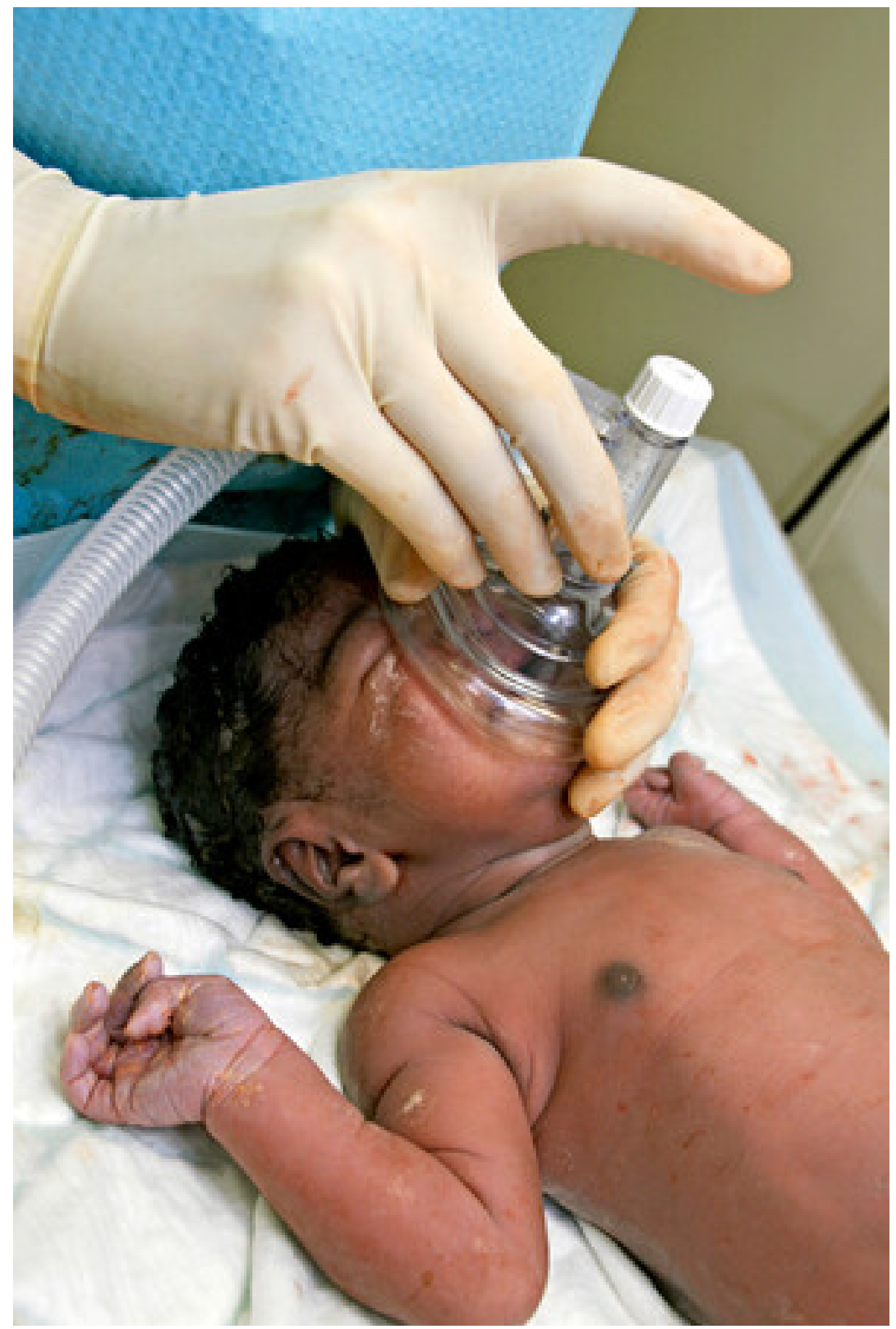

Illustrasjonsfoto: Science Photo Library / NTB

På verdensbasis dør hvert år rundt 700 ooo nyfødte pga. fødselskomplikasjoner, nesten alle i lavinntektsland. Rask og korrekt intervensjon, fremfor alt å få luft i barnet gjennom manuell ventilering, er det viktigste tiltaket for å få flere til å overleve. Dette kan gjøres med maske og bag eller ved å bruke en slange med kontrollert lufttrykk, koblet til et T-stykke med maske. Med sistnevnte alternativ kan man bruke en motstandsventil mot utpust, slik at man oppnår et positivt endeekspiratorisk trykk (PEEP). Slike systemer krever imidlertid tilgang på gass under trykk, og noen rapporter tyder på mye brukerfeil hos utrent personell. 
I en ny studie ble 417 nyfødte barn, født på Haydom Lutheran Hospital i Tanzania og som trengte gjenoppliving, randomisert til bruk av ventilasjonsbag med eller uten en motstandsventil som gir positivt endeekspiratorisk trykk (1ㅣ). Barna som ble gjenopplivet med en motstandsventil hadde litt lavere tidalvolum og $\mathrm{CO}_{2}$-nivå i utpustluften, men det var ingen forskjell mellom de to gruppene på hvordan det gikk med barna. Effekten på hjertefrekvens var omtrent lik i begge gruppene. Ett døgn etter fødsel var $9 \%$ av barna i begge gruppene døde.

- Disse funnene er overraskende fordi det internasjonalt er stor tro på at positivt endeekspiratorisk trykk fortrenger væsken i lungene raskere hos nyfødte som ikke puster ved fødsel, forklarer Kari Holte, som er overlege i pediatri ved Sykehuset i Østfold og studiens førsteforfatter. Langsommere stigning i $\mathrm{CO}_{2}$-nivået taler snarere for at det tok lenger tid å etablere effektiv gassutveksling i gruppen der motstandsventil ble benyttet.

Komiteen som lager internasjonale retningslinjer for gjenoppliving av nyfødte, anbefaler bruk av en motstandsventil for å oppnå positivt endeekspiratorisk trykk hos nyfødte uavhengig av svangerskapslengde ved fødsel (2) $)$. Denne norsk-tanzanianske studien taler imidlertid for at en slik ventil ikke har noen effekt hos barn født ved eller nær termin.

\section{LITTERATUR}

1. Holte K, Ersdal H, Eilevstjønn J et al. Positive end-expiratory pressure in newborn resuscitation around term: A randomized controlled trial. Pediatrics 2020; 146: e20200494. [PubMed][CrossRef]

2. International Liaison Committee on Resuscitation. Devices for administering Positive Pressure Ventilation (PPV) at birth: (NLS\#870) Systematic Review, draft for public comment.

https://costr.ilcor.org/document/devices-for-administering-positive-pressure-ventilation-ppv-atbirth-nls-870-systematic-review Lest 16.3.2021.

Publisert: 30. april 2021. Tidsskr Nor Legeforen. DOI: 10.4045/tidsskr.21.0209

(C) Tidsskrift for Den norske legeforening 2023. Lastet ned fra tidsskriftet.no 26. april 2023. 